\title{
The daily lives of people with Parkinson's disease
}

\author{
O cotidiano das pessoas com a doença de Parkinson \\ El cotidiano de las personas con la enfermedad de Parkinson
}

\section{Rafaela Vivian Valcarenghi', Angela Maria Alvarez', Silvana Sidney Costa Santos", Josiane Steil Siewert', Simony Fabíola Lopes Nunes'"', Andrelise Viana Rosa Tomasi'}

' Universidade Federal de Santa Catarina, Postgraduate Program in Nursing. Florianópolis, Santa Catarina, Brazil. "Universidade Federal do Rio Grande, School of Nursing, Department of Nursing. Rio Grande, Rio Grande do Sul, Brazil.

I' Universidade Federal do Maranhão, Department of Nursing. Imperatriz, Maranhão, Brazil.

Valcarenghi RV, Alvarez AM, Santos SSC, Siewert JS, Nunes SFL, Tomasi AVR. The daily lives of people with Parkinson's disease. Rev Bras Enferm [Internet]. 2018;71(2):272-9. DOI: http://dx.doi.org/ 10.1590/0034-7167-2016-0577

\section{Submission: 11-23-2016 Approval: 04-11-2017}

\begin{abstract}
Objective: To understand the daily lives of people with Parkinson's disease. Method: Qualitative research, using as methodological and theoretical referential the Grounded Theory and Symbolic Interactionism, respectively. The in-depth interview was conducted with 30 people with Parkinson's disease. Results: From data analysis, three themes were selected: Living with the disease - living with the treatment and changes in lifestyle; Modifying of one's job performance - revealing incapacity for work and the need to anticipate retirement and; Living with the stigma - the feeling of prejudice against the disease and the perceived limitations of the health services. Final considerations: Living with a chronic and non-transferable disease encompasses social, physical and cultural effects, along with the personal experiences of each unique individual. This study assists the improvement of care to people with the disease, because the care practice emerges from the interactions between the subjects.
\end{abstract}

Descriptors: Chronic Disease; Parkinson's Disease; Life-Altering Events; Qualitative Research; Nursing.

\section{RESUMO}

Objetivo: Compreender o cotidiano das pessoas com a doença de Parkinson. Método: Pesquisa qualitativa, utilizando como referencial metodológico e teórico a Teoria Fundamentada nos Dados e o Interacionismo Simbólico, respectivamente. A entrevista em profundidade foi realizada com 30 pessoas com a doença de Parkinson. Resultados: Por meio da codificação dos dados, emergiram três categorias: Vivendo a rotina da doença - a convivência com o tratamento e as modificações no viver; Modificando seu desempenho no trabalho - revelando incapacidade para o trabalho e a necessidade de antecipar a aposentadoria e; Convivendo com estigmas - o sentimento de preconceito pela doença e a percepção de limitações dos serviços de saúde. Considerações finais: A convivência com uma doença crônica não transmissível engloba efeitos sociais, físicos, culturais e as experiências pessoais de cada um. Este estudo auxilia no aprimoramento da assistência às pessoas com a doença, pois a prática de cuidados emerge das interações entre os sujeitos.

Descritores: Doença Crônica; Doença de Parkinson; Acontecimentos que Mudam a Vida; Pesquisa Qualitativa; Enfermagem.

\section{RESUMEN}

Objetivo: Comprender el cotidiano de las personas con la enfermedad de Parkinson. Método: Investigación cualitativa, utilizando como referencial metodológico y teórico la Teoría Fundamentada en Datos y el Interaccionismo Simbólico, respectivamente. La entrevista en profundidad fue realizada con 30 personas con la enfermedad de Parkinson. Resultados: Por medio de la codificación de los datos, emergieron tres categorías: Viviendo la rutina de la enfermedad: la convivencia con el tratamiento y las modificaciones en vivir; Modificando su rendimiento en el trabajo: revelando incapacidad para el trabajo y la necesidad de anticipar la jubilación y; Conviviendo con estigmas: el sentimiento de prejuicio por la enfermedad y la percepción de limitaciones de los servicios de salud. Consideraciones finales: La convivencia con una enfermedad crónica no transmisible 
engloba efectos sociales, físicos, culturales y las experiencias personales de cada uno. Este estudio auxilia la mejora de la asistencia a las personas con la enfermedad, pues la práctica de cuidados emerge de las interacciones entre los sujetos.

Descriptores: Enfermedad Crónica; Enfermedad de Parkinson; Hechos que Cambian la Vida; Investigación Cualitativa; Enfermería.

\section{CORRESPONDING AUTHOR Rafaela Vivian Valcarenghi E-mail: rafaelavalcarenghi@yahoo.com.br}

\section{INTRODUCTION}

Parkinson's disease (PD) is the second most common neurodegenerative disease of movement disorders, affecting the central nervous system. It is characterized by the reduction of nigrostriatal and cortical dopaminergic influence. The prevalence of PD in the population is of 550 cases per 100,000 inhabitants with 70 years of age $\mathrm{e}^{(1)}$.

In Santa Catarina, based on the Census from 2010, when the number of people with 70 years of age and older was 276,086 older adults, it was found that the prevalence of the disease in this age group was of 1,518 people. In this sense, the Florianópolis region has a prevalence of 275 older adults with PD aged 70 years and older ${ }^{(2-3)}$.

The characteristic signs and symptoms of PD result in the coexistence with new situations every day. The instability of the disease and the fact of it being known as incurable constitute a difficult reality to be faced with for the rest of one's life, accompanying individuals in their relationships and in their everyday life $\mathrm{f}^{(4)}$.

In addition, there is a strong interaction between PD and depression. A study conducted in seven different countries found a significant association between both, with about onethird of people having Parkinson's disease and also depression $^{(5)}$, a condition that needs special attention on the part of health professionals, in particular nurses.

Another relevant aspect concerns the individuality of people with the disease, because the meanings of the different motor and non-motor symptoms influence specifically each individual. Getting to know the reality of these people is fundamental to the understanding of the role of nurses in the care to the disease, since it is a condition that affects the motor system, the psychological aspect, the interaction with the family and society. In this context, it is understood that nurses needs to strengthen the relationship with the patient and family, getting to know their daily lives, in order to assist them in the process of living healthy ${ }^{(6)}$.

Therefore, this study aimed at understanding the daily lives of people with Parkinson's disease.

\section{METHOD}

\section{Ethical aspects}

The study was approved by the Ethics Committee in Research with Human Beings at the State University of Santa Catarina. Permission was also granted by the Santa Catarina Parkinson Association (APASC). All participants signed the Informed Consent Form (ICF). All stages of this research were based on Resolution 466/12 of the National Health Council ${ }^{(7)}$.

In order to preserve the identity of respondents, they were identified with the letter " $\mathrm{P}$ " of participant, followed by the number corresponding to the data collection, for example: participant of interview number 1 , thus $\mathrm{P} 1$, and so on, followed by gender, age and time of diagnosis.

\section{Theoretical-methodological framework}

The study had as Methodological Referential the Grounded Theory (GT). In this method, the researcher seeks to understand a complex social phenomenon through observation of the social setting, collecting and analyzing the information with the aid of an inductive and deductive approach ${ }^{(8)}$.

As theoretical framework, Symbolic Interactionism was used, which is based on social conduct, from which the significant symbols emerge, when individuals identify themselves with attitudes, behaviors and judgments ${ }^{(9)}$.

\section{Type of study}

This is qualitative type of research. This approach also describes details of situations in order to understand individuals in their environment, being mainly inductive, and demanding the investigator to be flexible and creative at the time of data collection and analysis. This approach assists nursing professionals in the understanding of reality, seeking the possible meanings for the subjects involved ${ }^{(10)}$.

\section{Methodological procedures}

\section{Study scenario}

The research occurred at APASC, which is a non-profit organization founded in 2004, as an initiative of people with the disease and professors of the Nursing Department at the Federal University of Santa Catarina, through the extension project "Mutual Help Group for People with Parkinson's Disease and their Families".

\section{Data source}

Thirty people with PD participated as informants in the study, all registered in the Association. The criteria for being part of this research were: having the Parkinson's disease diagnosis; having a preserved cognitive condition, according to the Mini Mental State Examination (MMSE) score; and being able to communicate verbally with the researcher.

This was followed by the precept of theoretical saturation of data, using three different sampling groups, according to the time of diagnosis of the disease: sample group 1 (subjects with less than 5 years of PD diagnosis: 14 participants); sample group 2 (subjects with 5 to ten years of PD diagnosis: 7 participants); and sample group 3 (subjects with over 10 years of PD diagnosis: 9 participants).

\section{Data collection and organization}

The data collection and analysis occurred concurrently, in the period from September 2013 to April 2014. Initially, the MMSE 
was applied. Then, in-depth interviews were held, which were recorded on mp3 and then transcribed and analyzed.

\section{Data analysis}

Data were analyzed according to the TFD encodings techniques - open encoding, axial encoding and selective encoding ${ }^{(8)}$.

Through such coding techniques, it was possible to unveil the categories and its subcategories that describe the phenomenon of everyday life with PD: Living with the disease (subcategories: Living with the treatment of the disease; Living one day at a time; and Changes in lifestyle); Modifying of one's job performance (subcategories: Revealing incapacity for work; and Anticipating retirement and; and Living with the stigma (subcategories: The feeling of prejudice against the disease and; The perceived limitations of the health services).

\section{RESULTS}

Regarding the characterization of the 30 informers, 19 were female and 11 male. In what concerns age, it ranged from 44 to 83 years old. In relation to the time of PD diagnosis, it ranged from four months to 20 years.

After the process of data analysis, three categories were created, supported by their respective subcategories.

\section{Living with the disease}

In this category, it was possible to get to know the daily life of the person with PD, in which a day is always different from the other, with ups and downs of the disease, with the improvement or worsening of the tremors, rigidity and other symptoms and signs. It is supported by the subcategories: "Living with the treatment of the disease," "Living one day at a time" and "Changes in lifestyle."

The way people with PD had been "living with the treatment of the disease" was assessed. The experience with medications is a difficult situation, because many make use of multiple medications due to other comorbidities.

Side effects from medicines intended for the disease and difficulty in relation to the dosages required were reported; other participants highlight the positive effects of the medications, which would have improved their daily living with the disease. It is interesting to note that the person learns the moment when the effect of the medication wears off and when they need to do something, like taking a new dose or resting, avoiding the performing of activities until the effects from the next dose begin to relieve the symptoms.

The use of many continuous-use medication triggers the feeling of having to live with a disease for their whole life; the effects, on the other hand, can mean suffering and discomfort. This reality can be identified in the reports:

I was having lots of nightmares at night, because of the medications. (P15, Male, 67 years old, 7 years of diagnosis)

When we take the medication, it controls things a bit more, I was suffering too much in the beginning, because I was not taking any medication, I couldn't even brush my own hair, and nowadays I have a firmer hand, but the tremors haven't stopped. (P14, Male, 47 years old, 2 years of diagnosis)

Living with the medications occurs in a positive way when the reduction of signs and symptoms is perceived; however, many people report that it is necessary to live with the side effects, so that it becomes more of a challenge to face.

Another aspect that was revealed was "Living a day at a time," because every day represents a different way of living with the disease, mainly due to the feelings related to the characteristic signs and symptoms of the condition of chronicity. Often, tremors or stiffness become more apparent, influencing the way one is feeling. This condition can be observed in the reports:

Yes, I think there are days we feel worse ... now I feel I get much worse when I get really nervous. (P5, Fem, 59 years old, 4 months of diagnosis)

[...] living with the disease, one day you're good, the other you're bad, in what concerns the symptoms. For example, I feel fine, I'm under the effect of the medicine, but with five minutes left for the effect of the medicine to wear off, I start shaking, every day. (P26, Male, 60 years old, 10 years of diagnosis)

You never know what tomorrow has in store, there are days like this, you're able to do everything you had planned to, the other day, you can't do anything, no matter how much you want to, times passes and you don't do anything, and some days you're awfully productive, you do everything you had planned to and the next day you can't do anything. There are days in which I have the physical condition necessary to do things, some days I don't. (P20, Male, 64 years old, 7 years of diagnosis)

With each new day, the person has to overcome the signs and symptoms and the limitations imposed on them. There is a constant struggle for maintaining autonomy and independence. Feeling good and able to carry out the activities planned for the day results in people coping better with the disease and in their interacting with others.

When it comes to everyday activities, people with PD should create strategies, as may be seen in the subcategory "Changes in lifestyle." The discomfort arising from the disease makes it so that daily tasks are performed with more difficulty and at a slower pace, and also causes physical changes such as intestinal changes, in addition to creating the need for devices to aid with mobility and also the need for caregivers. The reports show the main changes that occur in the life of people with PD:

Now it's not like the old days, when I used to be my own person, I had a car on hand and I went anywhere I wanted to. Now I depend on someone to go with me, I can't go by myself, and this has affected me, it used to make me mad, but now I'm accustomed to it. (P27, Fem, 79 years old, 20 years of diagnosis)

What I've realized is that each stress factor I'm subjected to, not your everyday stress, but something bigger, worsens my motor standard, so to speak, and when I get better, when I overcome this stress, I improve a little, but not back to the previous level, so it's a downslope, sometimes it goes up a 
little bit, but never back to the previous level. (P12, Fem, 51 years old, 2 years of diagnosis)

I have a lot of difficulty to feed myself, I drop a lot of food on the floor because I shake a lot. Walking is the same, I've collapsed four times already. A long time ago I had to change my signature thrice, because I couldn't reproduce it correctly, I don't know if it was because I got nervous, so I kept changing it until I found one that was easier to replicate. (P21, Male, 74 years old, 5 years of diagnosis)

Such changes may deeply affect a person, because they will not be able to perform everyday activities like they used to. Being able to perform daily tasks directly influences a good living with the condition. With the advancing of the disease, the changes can lead to the need for assistance from relatives or caregivers. These limitations are shared with other people, and can lead to low self-esteem, isolation and depression.

\section{Modifying of one's job performance}

The consequences of PD have strong symbolism on activities related to work, especially when the person discovers the disease at an early age. Many are diagnosed after retirement, others while they still work, and the latter experience problems at their jobs due to the characteristics of the disease. Some continue to work even after diagnosis, and only begin treatment after retiring, while others are forced to retire because of the illness. The related subcategories are "Revealing incapacity for work" and "Anticipating retirement."

The data revealed the difficulties experienced at work and the perception that productivity was no longer the same, "Revealing incapacity for work." This can be perceived by coworkers or by the individuals themselves, when noticing they no longer have the same vitality or that they have newfound difficulties, such as writing and reasoning. In the accounts, the difficulties perceived in the work environment may be noted:

[...] I continued working, kept doing so for three years, but I had a hard time. I'd get nervous because I worked with finances, and had to write things such as invoices, at that time everything was done manually. In addition to having a computer there, we used a typewriter and still did things by hand. So I moved a lot, my handwriting was... for the invoice we had to have nice handwriting, and I started practicing writing, I'd start with larger handwriting and try to gradually make it smaller. (P15, Male, 67 years old, 7 years of diagnosis)

[...] I was no longer the same, I could not perform the same tasks with the same speed, with the same energy, the pace was different. (P19, Fem, 46 years old, 6 years of diagnosis)

Work is important in people's lives, because, most often than not, it is through it that interpersonal relationships are formed; working makes people feel like they are actively being part of society, thus raising their self-esteem.

Another significant aspect is having to retire early, which can be very painful and often infuriating to people who need to do so, "Anticipating retirement." Many reveal how complex retirement is and how it affects their self-esteem, as noted in the reports:
[...] retirement was fast, I went twice there, the doctor said I didn't need to go anymore, that I was retired. I started taking walks, I'd wake up before sunrise and go walking outside, standing still is worse than working. I started getting depressed after diagnosis, when I stopped working, it really got to me, I'd wake up at the same time I used to. (P26, Male, 60 years old, 10 years of diagnosis)

So that aspect [of retirement], for me, was a disaster. I think I'm getting it back together now, but I still haven't found myself again... The doors are now closed, but my brain, thank God, at least for now is untouched. So it's a depressing situation, it was in this aspect that the disease most affected me. (P12, Fem .51 years old, 2 years of diagnosis)

\section{Living with the stigma}

This category shows the prejudice experienced by people with PD, which may occur due to the characteristics of the disease, such as tremors and stiffness, difficulty walking, in addition to the unpreparedness in relation to the disease. Its subcategories "The feeling of prejudice against the disease" and "The perceived limitations of the health services" are discussed below:

The people involved have noticed prejudice in relation to the signs of the disease, revealing the subcategory "The feeling of prejudice against the disease," which can occur through looks or comments by other people. This fact results in embarrassment and feelings of shame:

When I talk to a friend, I notice they feel sorry for us, a feeling of pity, and that's not cool. Those who have known me for quite some time: "Tough luck, you're not riding your bike anymore?" And me: "No, I have this issue." Then someone else finds out and says: "I've heard you have Parkinson's, that's unfortunate...", and this makes me feel even worse. I've noticed that people who are most affected by the disease get stared at in public... sometimes we go out together, and those who have got it worse are stared at, people seem to think "they're cripples," they don't know what it is, a lot of people don't... One thing I've learned is that many people do not know what Parkinson's disease is. (P8, Male, 58 years old, 3 years of diagnosis)

From time to time, people stare at me ... it's because of the tremors, but I try to hide it, I know how to do it, when it's too bad, I try to just hold on and hide it. (P10, Fem, 59 years old, 3 years of diagnosis)

In the beginning, when I was not doing too good, I'd notice... sometimes I'd walk down the street and there would be some neighbors talking nearby, and when I looked at them they'd be staring at me. (P11, Fem, 60 years old, 6 months of diagnosis)

The tremors and changes in walking pattern are understood by society as being different from the ordinary, which is why these signs and behaviors characteristic of the disease lead to stares from other people. On the one hand, there is the ignorance on $\mathrm{PD}$, as well as the understanding of it as being some other condition, as has been reported in the accounts. These perspectives and perceptions of prejudice that occur in public spaces are very significant for the person with PD, because 
they often prefer to stay at home to avoid interacting with others or try to disguise such signs to look healthy.

Through the reports, it is clear how embarrassed they feel for displaying certain characteristics of the disease. Some try to conceal the tremors, hiding their hands, so that the people around them won't identify the disease, as noted in the reports:

[...] I sometimes feel a little inferior to others, to my friends... it seems they notice it, I feel kind of ashamed, kind of standoffish. I used to be happier, nowadays I am more of an introvert. (P8, Male, 58 years old, 3 years of diagnosis)

[...] nowadays there are days when it's hard to eat, when I have to use a knife and fork, because the handling of the knife with my right hand, it's possible to some extent, but everyone who is around me tries to help, and it's embarrassing. (P12, Fem, 51 years old, 2 years of diagnosis)

I feel really ashamed to tell you the truth, but there's nothing I can do about it. I didn't use to be like that. I'm ashamed of people saying I'm shaking. Sometimes, they don't say it to my face, but behind my back, it gets me discouraged. (P14, Male, 47 years old, 2 years of diagnosis)

These feelings are difficult to deal with for the person with PD, showing just how much their self-esteem and self-confidence become shaken by the illness.

The subcategory "The perceived limitations of the health services" highlights the lack of training and the limitations of health professionals, as shown in the reports:

The first professional who told me about it, I found a little aggressive, it was kind of funny, he came in and said: "Yeah, I suspected that already." I thought: "Do I have a tumor in my head or something?". (P8, Male, 58 years old, 3 years of diagnosis)

About this issue of age, I think that they [health professionals] must pay a little more attention also to younger patients, since older adults are usually the main focus. Of course incidence is higher, we understand all this, but we become lost, because we don't see it that way... Out of all the programs they have, before I turn 60 years old, there's none I fit in... I think Medicine has to pay a little more attention to this aspect of treatment, knowing what is better for each patient, and the programs have to focus also on younger patients, because the disease has been affecting an increasingly higher number of younger people. (P9, Fem, 44 years old, 3 years of diagnosis)

\section{DISCUSSION}

Having to take medications rigorously, be it due to the need to control the signs and symptoms of the disease throughout the day, be it due to their side effects, is seen as something significant in the life of patients. The most common side effects of the medications for treating PD are: nausea, vomiting, diarrhea, constipation, episodes of akinesia, agitation, anxiety, hallucinations, delusions, dizziness, confusion, drowsiness, insomnia, depression, among others ${ }^{(11)}$.

One of the main medications used is levodopa. In a study on the use of levodopa, $39.3 \%$ of the patients reported side effects, the most frequent being involuntary movements (40\%). About $58 \%$ of the patients reported other symptoms such as sleepiness, dizziness, stomach cramps, heartburn, falls, constipation, weakness, malaise, precordial pain, anguish, redness of the skin, excessive salivation or a dry mouth. However, it was found that there was no certainty on the part of patients whether these symptoms were caused by levodopa, since they had doubts regarding the side effects of the drug ${ }^{(12)}$.

The PD patients represent a heterogeneous group, especially with regard to the type of treatment and to the patients' expectations. For a proper treatment, it is important to examine the various areas affected by the disease. When highlighting the patients' symptoms and their expectations regarding treatment, it is essential to encourage a dialogue between them and health professionals. This creates an environment of greater understanding, the educating/orienting of the patient being one of the most adequate strategies for adherence to treatment ${ }^{(13)}$.

In the intermediate and late stages of the disease, the adverse effects pertaining to the activities of everyday life are more pronounced than for people in the early stages. It is important to consider the routine with PD and in this way, conceive care programs according to the needs of each patient ${ }^{(14)}$.

Having a chronic neurological condition such as PD is worrisome for most people who experience changes in their social activities, work, relationships, physical mobility and independence ${ }^{(15)}$. Such aspects need to be taken into consideration, since they can generate limitations pertaining to daily life and decrease the interaction with other people due to feelings of sadness and anxiety.

The motor and emotional changes are what most influences the experience with PD. Knowing and understanding the factors that interfere in day-to-day perception improves and guides the care provided by health professionals. For patients, it is not enough to focus on the physical aspects of the disease only, but also on other dimensions, ensuring the maintenance of social relations, independence and autonomy for longer ${ }^{(16-17)}$.

The adaptation to life with PD, with the limitations and difficulties of everyday life, is revealed through the awareness of the need for better caring for one's own self ${ }^{(4)}$. This shows the relevance of the nurse's assistance in encouraging self-care and promoting health, so that patients may live more comfortably with the disease despite the changes that occur along its development.

In addition, it is relevant to conceive and implement strategies to promote the performance of people with PD in carrying out daily activities and more difficult tasks, even in the early stages of the disease, enabling the maintenance of independence, decreasing of the functional decline and a better quality of life(18).

Feeling capable and productive when accomplishing tasks is something indispensable to human beings. It is through work that a person feels they belong in society, influencing their lives. Health professionals should be ready to act in these aspects, stimulating activities that help in preventing the development of limitations and promoting self-esteem.

Another relevant factor concerns early retirement. In Brazil, sick pay and retirement due to invalidity, together, accounted 
for about $51 \%$ of the total of benefits granted in 2004 in the country. Such magnitude has important economic and social repercussions in the Brazilian social security system. These are benefits that were granted to people in the working age range, particularly those affected by diseases resulting from the process of industrialization and urbanization ${ }^{(19)}$.

Retirement is considered a stressful event in the life of people with $\mathrm{PD}^{(20)}$. After years of work, being faced with retirement imposes changes in the lives of individuals. This stage of life is filled with memories and feelings, because, through work, people feel useful to society. Retirement still represents the beginning of old age ${ }^{(21)}$.

Thus, the need to retire due to health condition is pervaded by stigma, leading to sadness, feelings of failure and uncertainty about the future.

The age factor is an important aspect when it comes to difficulty in retiring, because people in the working age range find problems dealing with this process. With regard to retirement, rarely studied as a health risk factor, people often deny interventions that would minimize the effects of risk factors present in the transition to this new social condition ${ }^{(22)}$.

Feeling embarrassment over the manifestation of the signs and symptoms of the disease is another relevant factor mentioned by the participants, especially with regard to the stigma associated with tremors, speech difficulties and postural instability; and also emotional insecurity, as the condition may change one's overall mood, possibly leading to dismay, sadness and depression ${ }^{(23)}$.

In addition to the prejudice perceived in the interaction processes and in public spaces, there is also the feeling of self-prejudice, shown through the feelings of shame over one's condition, which is evidenced, for example, by the tremors and slowness when walking. In some cases, the low morale and feelings of shame appear to overcome the desire to maintain social conviviality, despite encouragement from the family ${ }^{(4)}$.

This reality demands that actions are carried out so as to inform people, family and the community in general about the disease, symptoms and treatments, in order to shed light on the possibilities of life with PD. Only with the socialization of the knowledge on how the disease affects people will it be possible to replace the image associated with PD.

In addition, a good relationship between health professionals and people affected by this chronic condition is needed. The professional needs to adapt the care to people with PD considering their individuality, wishes, complaints and questions, sharing treatment choices according to the age and evolution of the disease.

One of the characteristics of the therapeutic relationship is that both professional and patient transform or modify their behavior and learn from the outcome of this interactive process. In addition to treatment, another aspect that impacts the bond between health professional and patient/family is the communicating of a chronic disease diagnosis; this should be better addressed by the professionals, because the way the diagnosis is given influences the feelings and behaviors that shall accompany individuals and their families in the process of struggling against the disease ${ }^{(24)}$.
Another condition that affects the satisfactory interaction between professionals and patients is the ability of listening, communication and empathy, fundamental for a deferential relationship. In patient-centered care, the professional needs to demonstrate an interest for the person who is undergoing treatment, and lead conversations so as to meet the needs brought by each person ${ }^{(25)}$.

It is also very important, for the effective care to the person with PD, that interventions are implemented by a trained and/ or multidisciplinary team. In a study conducted in Canada, it was pointed out that the care administered by a team of specialists in movement disorders, nurses who specialize in PD and a social worker improved the levels of quality of life and depression in people with the disease ${ }^{(26)}$, a reality that deserves to be implemented in other countries, such as in Brazil.

\section{Study limitations}

The limitations of the study refer to the lack of scientific national and international production, in particular, studies performed by nurses and that encompass the experience with PD. It is necessary to carry out further research with people who exhibit such condition and do not participate in Associations related with PD to understand other realities.

\section{Contributions to the field of nursing, health or public policy}

As contributions to the study of Nursing, it was identified how complex it is for a person to live with PD. The study will provide relevant information that may influence the production mode of care to people with PD, who try to adapt themselves to and better deal with the changes caused by the disease. Understanding this experience is of paramount importance to health care professionals, so they may be attentive not only to the motor features of the disease, but also to the feelings and needs of each person.

\section{FINAL CONSIDERATIONS}

Through the study it was possible to understand the experience with PD. Such understanding enables nurses to become attentive to the person with this condition, because the practice of care emerges from the interactions between subjects, and this relationship influences how it is conducted.

It is understood that the coexistence with an NCD, such as DP, is full of meanings and encompasses social, physical, cultural effects and the personal experiences of each person. The experience with PD pervades the confrontation or not of the situation of chronicity. Living the day-to-day is living one day at a time, either due to the treatment of PD, or to the changes imposed by the disease.

In everyday life with the disease, the relationship with professional work and the feeling of inability or the anticipation of retirement also outstand. Living with the stigma - both due to the feeling of prejudice on the part of society and to the limitations of the health services aimed at people with PD, and also to the shame felt over the condition - refers to important aspects that need to be known and (re)assessed. 


\section{REFERENCES}

1. Baumann CR. Epidemiology, diagnosis and differential diagnosis in Parkinson's disease tremor, Parkinsonism Relat Disord[Internet]. 2012 [cited 2014 Apr 23];18(1):90-2. Available from: http://www.sciencedirect.com/science/article/pii/S1353802011700293

2. Brasil. Instituto Brasileiro de Geografia e Estatística (IBGE). CENSO 2010 [Internet]. Santa Catarina; 2010 [cited 2014 Dec 02]. Available from: http://www.ibge.gov.br/home/estatistica/populacao/censo2010/tabelas_pdf/total_populacao_santa_catarina.pdf

3. Pinheiro JES. Doença de Parkinson e outros transtornos do movimento. In: Freitas EV, Py L. Tratado de Geriatria e Gerontologia. $3^{\text {a }}$ ed. Rio de Janeiro: Guanabara Koogan, 2011. p.285-291.

4. Navarro-Peternella FM, Marcon SS. A convivência com a doença de Parkinson na perspectiva do parkinsoniano e seus familiares. Rev Gaúcha Enferm[Internet]. 2010 [cited 2014 Dec 15];31(3):415-22. Available from: http://www.scielo.br/pdf/rgenf/v31n3/ v31n3a02.pdf

5. Chagas MHN, Moriyama TS, Felício AC, Sosa AL, Bressan RA, Ferri CP. Depression increases in patients with Parkinsons disease according to the increasing severity of the cognitive impairment. Arq Neuro-Psiquiatr[Internet]. 2014 [cited 2014 Dec 15];72(6):426-9. Available from: http://www.scielo.br/pdf/anp/v72n6/0004-282X-anp-72-06-426.pdf

6. Souza JM, Barbosa AC, Silva ALF, Campos Júnior AP. Doença de Parkinson: atribuição de enfermagem na interação famíliadoente. Interdiscip Rev Eletrônica UNIVAR [Internet]. 2014 [cited 2014 Nov 23];11(1):96-101. Available from: http://revista. univar.edu.br/index.php/interdisciplinar/article/view/281

7. Brasil. Resolução n 466/2012. Diretrizes e normas regulamentadoras de pesquisas envolvendo seres humanos. Brasília: Conselho Nacional de Saúde; 2012.

8. Strauss A, Corbin J. Pesquisa qualitativa: técnicas e procedimentos para o desenvolvimento de teoria fundamentada. $2^{\mathrm{a}}$ ed. Porto Alegre: Artmed, 2008.

9. Carvalho VD, Borges LO, Rêgo DP. Interacionismo simbólico: origens, pressupostos e contribuições aos estudos em psicologia social. Psicol Ciênc Prof [Internet]. 2010[cited 2014 Nov 23];30(1):146-61. Available from: http://www.scielo.br/pdf/pcp/v30n1/ v30n1a11.pdf

10. Adue IM, Chervo MA, Carraro TE, Prado ML. Las Controversias entre Cuantificación y Cualificación en Investigación. In: Prado ML, Souza ML, Carraro TE (Orgs.). Investigación Cualitativa en Enfermería: contexto y bases conceptuales. Série Paltex Salud y

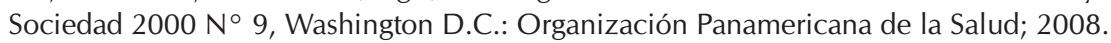

11. Dicionário de Especialidades Farmacêuticas-DEF. n. 42. Rio de Janeiro: Publicações Científicas, 2014.

12. Marchi KC,Chagas MH, Tumas V, Miasso Al, Crippa JA, Tirapelli CR. Adherence to medication among patients with Parkinson's disease treated at a specialized outpatient unit. Ciênc Saúde Colet[Internet]. 2013 [cited 2015 Apr 24];18(3):855-62. Available from: http://www.ncbi.nlm.nih.gov/pubmed/23546212

13. Nisenzon AN, Robinson ME, Bowers D, Banou E, Malaty I, Okun MS. Measurement of patient-centered outcomes in Parkinson's disease: what do patients really want from their treatment? Parkinsonismo Relat Disord [Internet]. 2011 [cited 2015 Apr 24];17(2):89-94. Available from: http://www.ncbi.nlm.nih.gov/pubmed/20952243

14. Pereira MP, Pelicioni PHS, Gobbi LTB. Parkinson's disease severity and motor subtype influence physical capacity components. Motriz Rev Educ Fis [Internet]. 2013[cited 2015 Apr 23];19(3):605-13. Available from: http://www.scielo.br/pdf/ motriz/v19n3/11.pdf

15. Rod NH, Bordelon Y, Thompson A, Marcotte E, Ritz B. Major life events and development of major depression in Parkinson's disease patients. European J Neurology [Internet]. 2013 [cited 2015 Apr 23];20(4):663-70. Available from: http://www.ncbi.nlm. nih.gov/pubmed/23114037

16. Filippin NT, Martins JS, Dela LLB, Halberstadt BF, Severo AR. Qualidade de vida de sujeitos com doença de Parkinson e seus cuidadores. Fisioter Mov[Internet]. 2014[cited 2015 Apr 23];27(1):57-66. Available from: http://www.scielo.br/pdf/fm/v27n1/01035150-fm-27-01-0057.pdf

17. King LA, Priest KC, Nutt J, Chen Y, Chen Z, Melnick M, et al. Comorbidity and Functional Mobility in Persons with Parkinson Disease. Arch Phys Med Rehabil [Internet]. 2014 [cited 2015 Apr 23];95(11):2152-7. Available from: http://www.ncbi.nlm.nih. gov/pubmed/25102383

18. Foster ER. Instrumental activities of daily living performance among people with parkinson's disease without dementia. Am J Occup Ther [Internet]. 2014 [cited 2015 Apr 23];68(3):353-62. Available from: http://www.ncbi.nlm.nih.gov/pubmed/24797199

19. Moura AAG, Carvalho EF, Silva NJC. Repercussão das doenças crônicas não transmissíveis na concessão de benefícios pela previdência social. Ciênc Saúde Colet[Internet]. 2007[cited 2015 Abr 23];12(6):1661-72. Available from: http://www.scielosp. $\mathrm{org} / \mathrm{pdf} / \mathrm{csc} / \mathrm{v} 12 \mathrm{n} 6 / \mathrm{v} 12 \mathrm{n} 6 \mathrm{a} 25 . \mathrm{pdf}$

20. Vlajinac H, Sipetic S, Marinkovic J, Ratkov I, Maksimovic J, Dzoljic E, et al. The stressful life events and parkinson's disease: a case-control study. Stress Health [Internet]. 2013 [cited 2015 Apr 23];29(1):50-5. Available from: http://www.ncbi.nlm.nih.gov/ pubmed/22396022 
21. Fontoura S, Doll J, Oliveira SN. The challenge of retiring in the contemporary world. Educ Real [Internet]. 2015 [cited 2015 Apr 24];40(1):53-79. Available from: http://www.scielo.br/pdf/edreal/v40n1/en_2175-6236-edreal-40-01-00053.pdf

22. Canizares JCL, Jacob Filho W. Fatores de risco à senilidade na transição à aposentadoria. Rev Bras Geriatr Gerontol [Internet]. 2011[cited 2015 Apr 23];14(3):425-32. Available from: http://www.scielo.br/pdf/rbgg/v14n3/v14n3a03.pdf

23. Santos ISC, Menezes MR, Souza AS. Concepções de idosos sobre a vivência com a doença de Parkinson. Rev Enferm UERJ[Internet]. 2009[cited 2015 Apr 23];17(1):69-74. Available from: http://www.facenf.uerj.br/v17n1/v17n1a13.pdf

24. Navarro-Peternella FM, Marcon SS. [Diagnosed with Parkinson's Disease: impact on patients and family members]. Rev Bras Enferm[Internet]. 2009[cited 2015 Apr 23];62(1):25-31. Available from: http://www.scielo.br/pdf/reben/v62n1/04.pdf Portuguese

25. Gomes AMA, Aprara A, Landim LOP, Vasconcelos MGF. Relação médico-paciente: entre o desejável e o possível na atenção primária à saúde. Physis[Internet]. 2012[cited 2015 Apr 23];22(3):1101-19. Available from: http://www.scielo.br/pdf/physis/ v22n3/14.pdf

26. Marck MA, Bloem BR, Borm GF, Overeem S, Munneke M, Guttman M. Effectiveness of multidisciplinary care for Parkinson's disease: a randomized, controlled trial. Mov Disord[Internet]. 2013 [cited 2015 Apr 23];5(28):605-11. Available from: http:// onlinelibrary.wiley.com/doi/10.1002/mds.25194/epdf 